\title{
Marx o potrebi \\ za umjetnošću: umjetnost između političke ekonomije i samoodredenja
}

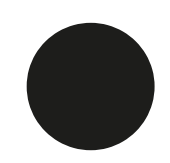

\section{Marx on the}

Need for Art: Art Between Political Economy and Self-determination 
PRETHODNO PRIOPĆENJE

Predan: 1.3.2019.

Prihvaćen: 18.6.2019.

DOI: $10.31664 / z u .2019 .104 .06$

UDK: 7.01:141.82]:330.1

SAŽETAK

Ako znamo da politička ekonomija proučava način na koji društvo zadovoljava svoje potrebe, očekivali bismo da će prikaz Marxove kritike političke ekonomije umjetnosti krenuti od kritike načina na koji se potreba za umjetnošću percipira unutar kapitalističkih proizvodnih odnosa. U ovom radu pokušat ćemo skicirati takvu kritiku, uzimajući različite prikaze položaja i uloge umjetnosti u sustavu ljudskih potreba kao kontekst u kojem su umjetnička djela i stvaralaštvo povezani s kategorijama robe, proizvodnje, rada, tržišta itd. Zatim ćemo se okrenuti prikazu ljudskih potreba kako in vidi Agnes Heller, a koje nisu ograničene na političku ekonomiju, i pokušati pokazati da je potreba za umjetnošću s pravom smještena u sustav „, neotuđenih” potreba i ljudskog samoodređenja.

KLJUČNE RIJEČI

umjetnost, politička ekonomija, potreba, permanentna revolucija, državno financiranje umjetnosti
PRELIMINARY PAPER

Received: March 1, 2019

Accepted: June 18, 2019

DOI: $10.31664 / z u .2019 .104 .06$

UDK: 7.01:141.82]:330.1

ABSTRACT

If we take political economy to be concerned with the way a society satisfies its needs, we would expect that an account of Marx's critique of political economy of art should begin with a critique of the way a need for art is perceived within capitalistic production relations. We will try to provide a sketch of such a critique in this paper, taking various accounts of the place and role of art within a system of human needs as a context in which art works and artistic creation are connected with categories of commodity, production, labour, market etc. Then we will turn to an account of human needs, provided by Agnes Heller, that are not limited to political economy and aim to show that the need for art is properly located within that system of "non-alienated" needs and human self-determination.

\section{KEYWORDS}

art, political economy, need, permanent revolution, governmental funding of art

\section{Bojan Blagojević}


UVOD

Tema ovog rada bit će pokušaj tematizacije uloge umjetnosti u marksističkoj filozofiji. Glavno će pitanje pritom biti: predstavlja li politička ekonomija prikladan kontekst za razmatranje pitanja koja se tiču umjetnosti? Što znači tvrdnja da je umjetnost potreba? Je li zadovoljavanje potrebe nužno povezano s konceptima robe, tržišta, viška vrijednosti, podjele rada i tome slično? Kako bismo odgovorili na ova pitanja, moramo prikazati uobičajene načine na koje buržujska estetika shvaća umjetnost. Prvi dio tog zadatka odnosit će se na Marxova razmišljanja o cenzuri i slobodi tiska. Drugi će dio pokušati dokazati da se glavna pitanja koja se postavljaju u njegovim djelima mogu primijeniti i na eventualno čitanje Marxove kritike suvremene buržujske estetike. Na kraju ćemo se posvetiti alternativnim viđenjima uloge umjetnosti: što bi mogla biti Marxova koncepcija uloge umjetnosti? Odgovor na to pitanje zahtijeva da prvo preispitamo njegovo poimanje potrebe i prirode kako bismo pokazali da, usprkos inherentnim proturječjima u njegovu promišljanju koncepta potrebe, postoji konstantna tendencija stvaranja novog koncepta povezanog s onim što Agnes Heller naziva „neotuđenim potrebama”. ${ }^{1}$ Tu ćemo pokušati smjestiti potrebu za umjetnošću koja nije sadržana u političkoj ekonomiji.

\section{MARX}

KAO ESTETIČAR

lako Marx nikada nije izložio sustavnu teoriju estetike, a komentare je ograničio na teme povezane s književnošću, postoje brojni pokušaji da se rekonstruira njegov stav. ${ }^{2}$ Kao što primjećuje O.K.Werckmeister, tu se mogu razlikovati dvije glavne tendencije:

O toj su pretpostavci napisani veliki, više ili manje sustavni priručnici o „marksističkoj estetici”, a takva se estetika predaje na komunističkim akademskim institucijama. S druge strane, s obzirom na to da se Marx, u svojem kontinuiranom nastojanju da potkrijepi teoriju povijesti i društva kroz desetljeća metodičnih istraživanja, nikada nije vratio ranijim interesima za estetiku, znanstvenici iz kapitalističkih zemalja zaključili su da je očito smatrao kako umjetnost ne spada u primarni materijal u kojem se može pratiti povijesni napredak prema socijalističkoj budućnosti. Nasuprot tome, službena komunistička estetika shvaća umjetnost kao kulturnu instituciju važnu za nastavljanje procesa ostvarivanja besklasnog društva. ${ }^{3}$

Kako bismo se odlučili za jednu od tih strana, moramo napraviti razliku između različitih pitanja koja mogu proizaći iz iščitavanja Marxove estetike. Fredric Jameson razlikuje deskriptivno (o ulozi koju je umjetnost igrala tijekom povijesti ili koju bi imala u zdravom društvu) i preskriptivno pitanje (o ulozi koju bi umjetnost trebala igrati u socijalističkom društvu ili društvu koje teži socijalizmu). ${ }^{4} \mathrm{U}$ ovom ćemo dijelu predstaviti Marxovo shvaćanje uloge koju je pruska država

\section{INTRODUCTION}

The topic of this paper will be an attempt to thematise the role of art within Marx's philosophy. Our main questions will be: is political economy the adequate context for discussing the questions pertaining to art? What does it mean to assert that art is a need? Is satisfying a need necessarily connected with the concepts of commodity, market, surplus value, division of labour and the like? To answer these questions, we will need to provide an account of the standard ways the role of art is perceived within bourgeois aesthetics. The first part of this task will concern Marx's writings on censorship and freedom of the press. The second part will aim to show that the main issues presented in these writings are still at work in what would be a reading of Marx's critique of contemporary bourgeois aesthetics. Finally, we will turn to the alternative accounts of the role of art: what could Marx's conception of the role of art be? In order to answer that question, we will turn to his notion of need and nature, and aim to show that, in spite of inherent contradictions present in his account of the concept of need, there is a constant tendency to create a new concept of what Agnes Heller calls "non-alienated needs." ${ }^{1}$ It is here that we will attempt to locate the need for art that is not contained within political economy.
1 Heller, Theory of Need in Marx, 27. 2 Vidi, na primjer: Morawski, „The Aesthetic Views of Marx and Engels”; Lukács, "Einführung in die ästetischen Schriften von Marx und Engels"; Lipshitz, The Philosophy of Art of Karl Marx; Koch, Marxismus und Ästhetik; Rose, Marx's Lost Aesthetic: Karl Marx and the Visual Arts; Prawer, Karl Marx and World Literature; Arvon, Marxist Esthetics; itd. 3 Werckmeister, „Marx on Ideology and Art”, 501-502. 4 Uvodnik Frederica Jamesona u: Arvon, Marxist Esthetic, xi. 
nametnula umjetnosti (odnosno književnosti) i pokazati da iz toga možemo naslutiti koju bi joj ulogu on sam dodijelio. U sljedećim ćemo dijelovima nastaviti s daljnjim razrađivanjem tog stava.

lako je u mladosti na njega utjecao romantizam i Fichteova radikalna distinkcija između onoga „što jest” i „što bi trebalo biti”, početkom 1840-ih Marx se okrenuo kritici reakcionarnog režima Fredericka Williama IV., koji je koristio romantizam kao svoju službenu ideologiju. Ta činjenica ima dvostruku važnost.
Heller, Theory of Need in Marx, 27

2

See, for example: Morawski, "The Aesthetic Views of Marx and Engels;" Lukács, "Einfuihrung in die ästetischen Schriften von Marx und Engels;" Lifshitz, The Philosophy of Art of Karl Marx; Koch, Marxismus und Ästhetik; Rose, Marx's Lost Aesthetic; Prawer, Karl Marx and World Literature; Arvon, Marxist Esthetics; etc.

Werckmeister, "Marx on Ideology and Art," 50I-502.

Frederic Jameson's introduction in: Arvon, Marxist Esthetic, xi. 5

Marx, "Remarks on the Instructions to the Prussian Censors," 59.
Although Marx never presented a systematic aesthetic theory, and has limited his comments to the topics of literature, there are numerous attempts to reconstruct his position. ${ }^{2}$ As O.K. Werckmeister notices, we can distinguish two main tendencies concerning this possibility:

Large, more or less systematic handbooks on "Marxist aesthetics" have been written on this assumption, and such an aesthetics is being taught in communist academic institutions. On the other hand, scholars in capitalist states have concluded that if Marx, in his sustained effort to substantiate his theory of history and society through decades of methodical research, never returned to his early interest in aesthetics, he must have considered that art did not form any part of the primary material in which the historical progress towards a socialist future could be traced. By contrast, official communist aesthetics conceives of art as a cultural institution with a relevance for the continuing process of bringing the classless society about. $^{3}$

If we want to decide which side we want to join, it is important to distinguish various questions that a reading of Marx's aesthetic can put forward. Fredric Jameson discerns between the descriptive (about the role that art played in history, or would play in a healthy society) and the prescriptive question (the role that art ought to play in a socialist society or a society striving towards socialism). ${ }^{4}$ In this section, we will present Marx's account of the role that the Prussian state imposed onto art (i.e. literature) and show that we can even in those conditions glimpse the role that he would have assigned to art. In the following sections we will proceed with further elaborations of this view.

Although influenced in his youth by romanticism and Fichte's radical distinction of "what is" and "what ought to be," in the beginning of the I840s Marx turns to the critique of the reactionary regime of Frederick William IV, which used romanticism as its official ideology. This fact bears a double significance.

First, there is a change of policy towards press: instead of requiring a monetary guarantee of "good behaviour," the new regulations required of editors "literary ability" and "social status," to be determined by the official censor and his whims, or rather, his loyalty to the regime. Marx lamented on this in his $184^{2}$ text "Remarks on the Instructions to the Prussian Censors:”

The law permits me to write; it asks only that I write in a style other than my own! I am allowed to show the face of my mind, but, first, I must give it a prescribed expression. ${ }^{5}$ 
Prije svega, došlo je do promjene politike prema tisku: umjesto da zahtijevaju novčane garancije „dobrog ponašanja”, nova pravila propisala su da urednici moraju imati „literarne sposobnosti” i „društveni status”, čije je utvrđivanje ovisilo o službenom cenzoru i njegovim hirovima, odnosno njegovoj odanosti režimu. Marx se na to žalio u svojem tekstu iz 1842. godine „Remarks on the Instructions to the Prussian Censors" [Primjedbe uputama pruskih cenzora]:

Zakon mi dopušta da pišem; samo od mene traži da pišem stilom koji nije moj vlastiti! Dopušteno mi je pokazati lice svojega uma, no prvo ga moram postaviti u propisani izraz. ${ }^{5}$

Druga je poanta značajnija, ali Marx je u to vrijeme ipak nije svjestan: reakcionarni romantizam Fredericka Williama IV. napravio je važan korak od feudalnog fetišiziranja religije do buržujskog fetišiziranja umjetničkih djela. Kao što je primijetio Mikhail Lipshitz:

Kada je, u kasnijim godinama, prilikom pisanja o fetišizmu robe Marx potražio analogiju u „nebuloznom svijetu religije”, na umu je imao upravo onu značajku religijskog gledišta koja je u sporazumu iz 1842. figurirala kao osnovni uzrok antagonizma između umjetnosti i religije... Marx je tada još bio daleko od shvaćanja da je taj najnoviji fetišizam i sam bio rezultat temeljnog načina proizvodnje. I zato u izvacima iz 1842. ne nalazimo ništa što bi iole sličilo Marxovim kasnijim stavovima o povijesnom nerazmjeru između razvoja produktivnih sila društva i njegova umjetničkog rasta. Upravo suprotno, ovdje se umjetnost i tehničke vještine čine ujedinjenima u svojoj opoziciji arhaičnom i modernom barbarizmu. ${ }^{6}$

Vratimo li se Marxovim primjedbama o cenzuriranju, vidjet ćemo da se, premda se prvenstveno odnose na slobodu tiska, mogu primijeniti i na književnost. Isto tako, Marx govori o „piscima” bez dodatnog specificiranja. Kada Marx piše: „Pisac, naravno, mora zarađivati za život da bi postojao i mogao pisati, ali ni u kojem smislu ne mora postojati i pisati da bi zarađivao za život... Pisac ni na koji način svoj rad ne smatra sredstvom. Pisanje je svrha samom sebi", ${ }^{7}$ misli na novinare, kao i na pjesnike, a to kasnije ponavlja i u Komunističkom manifestu. ${ }^{8}$ Buržujski odnosi svako zanimanje pretvaraju u nadničare, a svaki zanat podvrgavaju općim pravilima za sve zanate. No Marx inzistira na tome da sloboda tiska (a onda i književnosti) leži upravo u činjenici što to nisu zanati pa ih se ne bi trebalo podvrgavati takvim vanjskim standardima. Umjesto pravila struke, pruska je država uvela razliku između ,autoriziranih” i „neautoriziranih" pisaca, čime je pripremila teren za instrumentaliziranje tiska i književnosti u korist svoje ideologije, pretvarajući ih u „remetilačke elemente” koji učvršćuju „klasne razlike” i prihvaćajući „otupjelost i glupost” kao svoja pravila. ${ }^{9}$ Namjera pruske države bila je jasna: nakon reformacije religija više nije mogla osigurati lažnu ideju ujedinjene
The second point is more significant, but Marx is still unaware of it at the time: reactionary romanticism of Frederick William IV takes an important step from the feudal fetishism of religion to the bourgeois fetishism of artwork. As Mikhail Lipshitz notices:

When, in later years, speaking of commodity fetishism, Marx turned for an analogy to the "nebulous world of religion," he had in mind that very trait of the religious outlook which in the treatise of 1842 figured as the fundamental cause of the antagonism between art and religion... Marx at that time was still far from understanding that the newest fetishism was itself a product of a definite mode of production. And so we do not find in the excerpts of I842 anything even remotely resem bling Marx's later views on the historical disproportion between the development of the productive forces of society and its artistic growth. Quite the contrary, art and technical skill here appear united in their opposi tion to archaic and modern barbarism. ${ }^{6}$

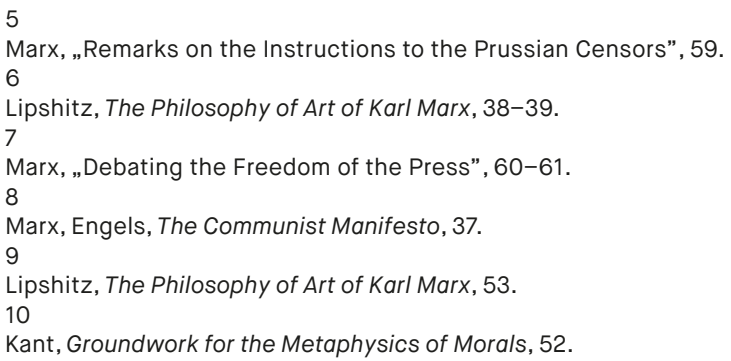


zajednice jednakih pa je morala biti zamijenjena mitovima romantizma. Pisac i njegovo djelo smatrani su samo sredstvom za ostvarivanje cilja, robom koja zadovoljava potrebe režima. No, kao što smo vidjeli, Marx nije prihvaćao takvo stanje stvari. Pozivajući se na koncept cilja samog za sebe, referirao se na Kantovu ideju ljudskog dostojanstva, temeljne ljudske značajke koju nije moguće komodificirati. ${ }^{10}$ Sada dolazimo do prvog dijela problema: ako o umjetnosti razmišljamo u smislu dostojanstva ili ideje o cilju samom za sebe, čini se da ne može postojati potreba za umjetnošću jer ona ne služi nikakvoj vanjskoj svrsi niti, posljedično, može imati ikakvu upotrebnu vrijednost. Prema toj interpretaciji, svaka instrumentalizacija umjetnosti predstavlja njezinu zlouporabu. Međutim, to možda i nije tako. Marxov stav o tom pitanju razradit ćemo dalje u tekstu, ali prvo ćemo se pozabaviti nekim standardnim buržujskim estetskim stavovima o ulozi umjetnosti, jer će nam biti potrebni kao premisa za naš daljnji argument.

6

Lifshitz, The Philosophy of Art of Karl Marx, 38-39.

Marx, "Debating the Freedom of the Press," 60-6r.

Marx, Engels, The Communist Manifesto, 37.

Lifshitz, The Philosophy of Art of Karl Marx, 53.

10

Kant, Groundwork for the Metaphysics of Morals, 52.
If we return to Marx's remarks on censorship, we will see that, although they primarily refer to the freedom of the press, they are also applicable to literature. Marx also refers to "writers" without further qualifications. When Marx writes: "The writer, of course, must earn a living to exist and be able to write, but he must in no sense exist and write so as to earn a living... In no sense does the writer regard his works as a means. They are ends in themselves," ${ }^{7}$ he is referring to both the writer of the press and the poet, as he later reiterates in The Communist Manifesto. ${ }^{8}$ The bourgeois relations turn every occupation into wage-labourers, submit every craft to the rules of crafts in general. But Marx insists that the freedom of the press (and literature, for that matter) lies exactly in the fact that they are not crafts, they are not trades and should not be submitted to such external standards. Instead of rules of the trade, the Prussian state introduces a distinction between "authorized" and "unauthorized" writers, thereby setting the stage for instrumentalizing both the press and literature for the purposes of its ideology, turning them into "disruptive elements" reinforcing "class divisions" and accepting "dullness and stupidity" as their rules. ${ }^{9}$ The intention of the Prussian state was clear: religion has since the Reformation become unable to provide the false idea of a unified community of equals, and myths of Romanticism had to take its place. The writer and his work were perceived only as means to that end, a commodity satisfying the needs of a regime. But as we have seen, Marx was not content with this state of affairs. By appealing to the concept of the end in itself, he refers to Kant's idea of human dignity, a fundamental human trait that cannot be commodified. ${ }^{10}$ Here we are faced with the first instance of the problem: if we are to think about art in terms of dignity or the idea of end in itself, it appears that there cannot be such a thing as a need for art, since it can neither serve any external purpose nor can it, consequently, possess any use value. Any instrumentalization of art is, according to this interpretation, an abuse of art. However, this may not be the case. We will return to elaborate Marx's stance on this issue in a later section. First, we will turn to some standard bourgeois aesthetic views concerning the role of art, as we will require those views as a premise in our further argument.

\section{THE NEED FOR ART: SOME BOURGEOIS ANSWERS}

We have reached a point where we need to make a distinction between two "types" of art we mentioned in the previous section. The first one would represent an answer to Jameson's “descriptive question” and would match the role that is imposed onto art by external authorities (whether it is the Prussian regime or contemporary bourgeois aesthetic standards). The second would be art as end in itself, the conception Marx insists on. We will use O.K. Werckmeister's distinction between professional "art production" as "a deviation from the human potential of art itself, because it is adapted to the needs and conditions of a working society whose organization is detrimental to 


\section{POTREBA ZA UMJETNOŠĆU: NEKI BURŽUJSKI ODGOVORI}

Došli smo do trenutka kada moramo napraviti razliku između dva „tipa” umjetnosti koje smo spomenuli u prethodnom dijelu. Prvi tip predstavlja odgovor na Jamesonovo „deskriptivno pitanje” i odgovara ulozi koju umjetnosti nameću vanjski autoriteti (bili oni pruski režim ili suvremeni buržujski estetski standardi). Drugi je tip umjetnost koja je sama sebi svrha, što je ideja na kojoj je inzistirao Marx. Upotrijebit ćemo Werckmeisterovu razliku između profesionalne „umjetničke proizvodnje” kao „devijacije od ljudskog potencijala same umjetnosti, zato što je prilagođena potrebama i uvjetima radnog društva čija je organizacija štetna za ljudsku prirodu” nasuprot „talentu” kao „,prirodnoj ljudskoj sposobnosti, koju je potrebno osloboditi profesionalizacije kako bi se prakticirala u skladu sa svojom biti". ${ }^{11}$ Tako bi buržujski odgovor na pitanje o potrebi za umjetnošću ustvari odgovarao na pitanja zašto nam je uopće potrebna profesionalna umjetnička proizvodnja.

Već smo dali kratak nacrt jednog od mogućih odgovora na postavljeno pitanje u prethodnom dijelu, kada smo spomenuli instrumentalizaciju tiska i književnosti za potrebe pruskog režima. Gordon Graham u svojoj knjizi Philosophy of the Arts [Filozofija umjetnosti] daje pregled nekih načina na koji se odvija ta instrumentalizacija. Prvo ćemo razmotriti tezu prema kojoj je „vrijednost umjetnosti... kognitivna, odnosno [umjetnost] ima vrijednost kao izvor znanja i razumijevanja”. ${ }^{12}$ Ako želimo vidjeti kako umjetnost može služiti kao sredstvo buržujske ideologije, možemo se poslužiti Grahamovim objašnjenjem: „Najvažnije je uvidjeti da umjetnička djela ne razjašnjavaju teorije niti sažimaju činjenice. Poprimaju oblik maštovitih ostvarenja koja se mogu primijeniti na svakodnevna iskustva kao način njihova uređivanja i osvjetljavanja." ${ }^{13}$ Premda se ovaj odlomak čini dosta benignim, samo se moramo prisjeti Marxovih riječi o stvaranju klasnih podjela i ulozi remetilačkih elemenata kako bismo shvatili ulogu koju umjetnička proizvodnja može imati i koju zaista igra u buržujskim ideologijama, pogotovo u stvaranju lažne svijesti. lako direktna državna kontrola i cenzura danas zasigurno nisu dominantni elementi kao u Marxovo doba (no čini se da se vraćaju u modu), umjetnička proizvodnja i dalje se (zlo)upotrebljava (uglavnom kroz različite načine financiranja) kao moćan, no suptilan instrument za stvaranje Weltanschauunga.

Druga koncepcija umjetnosti jest umjetnost kao zabava: „vrijednost umjetnosti leži u njezinoj sposobnosti da nas zabavi". ${ }^{14}$ Umjetnost kao jedan oblik distrakcije čiji je cilj da nam pruži određenu vrstu užitka, zadovoljstvo zbog kojeg se čini da je sve u redu, ideja je koju preziru kritičari kao što je Adorno koji je smatraju samo sredstvom s pomoću kojeg buržujska ideologija slabi revolucionarni potencijal radničke klase, skrivajući proturječja koja su implicitna u postojećem poretku. the nature of man" opposed to "talent" as "a natural human capacity, which has to be emancipated from professionalization in order to be practiced according to its essence." 11 Thus, bourgeois answers to the question of the need for art would actually be answering the question why we need professional art production.

We have already provided a brief sketch for one of the possible answers to this question in the previous section, when we mentioned the instrumentalization of the press and literature for the purposes of the Prussian regime. Gordon Graham, in his Philosophy of the Arts, provides accounts of some of the ways this instrumentalization takes place. Let us consider first the thesis according to which "value of art is... cognitive, that is to say, [art is] valuable as a source of knowledge and understanding." ${ }^{12}$ To see how art can serve as a means of bourgeois ideology in this manner, we can observe Graham's clarification: “(I)t is essential to see that works of art do not expound theories, or consist in summaries of facts. They take the form of imaginative creations that can be brought to everyday experience as a way of ordering and illuminating it." ${ }^{13}$ Although this passage seems quite benign, we only need to recall Marx's remarks about creating class divisions, and serving as disruptive elements to comprehend the role art production can play, and well plays within bourgeois ideologies, especially in creating false consciousness. Although direct governmental control and censorship are certainly not the mechanisms predominantly used today, as they were in Marx's time (but they do seem to be coming back in fashion), artistic production is still (ab)used (mostly through various forms of financing) as a powerful but subtle Weltanschauung-creating tool.

Werckmeister, „Marx on Ideology and Art”, 507. 12 Graham, Philosophy of the Arts, 52 . 13 Isto, 74. 14 Isto, 6. 15 Isto, 31. 
Razmotrit ćemo još jedan odgovor na pitanje o potrebi za umjetnošću, a to je koncept koji Graham naziva ekspresivizmom: „ono što je najvažnije u umjetnosti su emocije, kako osjećaji umjetnika tako i emocionalan učinak djela na publiku". ${ }^{15}$ No, kako Graham primjećuje, ako ovu poziciju ne želimo svesti na kognitivizam, teško je vidjeti kako možemo izbjeći „psihologizam”, čije su najpoznatije reprezentacije dane u terapeutskim koncepcijama Aristotela i Freuda. Umjetnost se tada smatra jednim oblikom terapije, aktivnosti koja primjenjuje katarzu ili sublimaciju da pojedinca vrati u stanje psihičkog zdravlja koje karakterizira produktivnost.

Temeljno je pitanje koje sada moramo postaviti: kome je potrebna umjetnost? Prema navedenim buržujskim koncepcijama, je li umjetnost potreba pojedinaca? Ili je pak buržoazijska ideologija ta kojoj je potrebna umjetnost (odnosno profesionalna umjetnička proizvodnja) kao sredstvo održavanja statusa quo? S obzirom na sve koncepcije koje smo do sad obradili, čini se da je točan odgovor onaj potonji (moglo bi se reći da je jedan aspekt uspješnoga „umjetničkog proizvoda" sposobnost skrivanja te činjenice). Komodifikacija umjetnosti u buržujskim društvima još je jedan pokazatelj da je to tako. Ako umjetnici (ili proizvođači umjetnosti) zaista igraju uloge koje smo opisali u ovom dijelu, bilo bi ispravno reći da je njihov posao pružanje usluga dominantnoj ideologiji te da je u interesu te ideologije da na tržištu postoji stalna potražnja za takvim uslugama. Umjetnička djela koja proizvode komodificiraju se i vrednuju u skladu s „kvalitetom" pružene usluge.
Another conception is that of art as amusement: "value of art lies in its ability to entertain us." 14 That art is a form of distraction, with a goal of bringing us certain forms of pleasure, enjoyment that makes it seem like everything is in order, is a conception much detested by critics such as Adorno, who see in it but a device through which bourgeois ideology weakens the revolutionary potential of the working class, hiding the contradictions implicit in the existing order.

We will assess one more answer to the question of the need for art. That is the conception that Graham calls "expressivism:" "what matter most in art is emotion, both the feeling of the artist and the emotional impact of a work on its audience." ${ }^{15}$ However, Graham notices, if we are not to reduce this position to cognitivism, then it is hard to see how we can escape "psychologism," represented most famously in its therapeutic conceptions provided by Aristotle and Freud. Art is then seen as a form or therapy, an activity that uses katharsis or sublimation to restore the individual to the state of mental health, marked by productiveness.

The basic question we must ask now is: Who needs art? According to these bourgeois conceptions, is art the need of an individual, or is it rather the bourgeois ideology the one that needs art (that is to say, professional art production) as a means of maintaining the status quo? The latter is arguably the correct answer (one could argue that one of the aspects of a successful "art product" is the ability to conceal this fact), bearing in mind all the conceptions we have assessed so far. One further clue that this is the case is the commodification of art in bourgeois societies. If artists (or art producers) indeed perform the roles that we depicted in this section, it would be right to say that they are in the business of providing services for the dominant ideology, and it will be in the interest of that ideology that a constant demand for such services be created on the market. The artworks they produce will be commodified and valued according to the "quality" of service provided.

IS ART

REALLY A NEED?

We have noted that Marx's insistence that artworks should be ends in themselves seems to imply that there can be no need for art. In this section we will examine if Marx's conception of need allows for a different interpretation. As Agnes Heller remarks, Marx uses the concept of need to define terms, but he doesn't define or describe the very concept of need. ${ }^{16}$ For example, he defines commodity as an object outside us that, by some of its properties, satisfies human needs of some sort. ${ }^{17}$ However, that only means that there cannot be any commodity without the existence of some need; it does not mean that there can be no need that cannot be satisfied by a commodity of some sort. If that were the case, it would follow that need is an entirely economic concept. Either there would be no need for art, 


\section{JE LI UMJETNOST ZAISTA POTREBA?}

Već smo zamijetili da Marxovo inzistiranje da bi umjetnička djela trebala biti svrha samima sebi naizgled implicira da potreba za umjetnošću ne može postojati. U ovom ćemo dijelu istražiti dopušta li Marxova koncepcija potrebe drugačiju interpretaciju. Kao što je primijetila Agnes Heller, Marx se koristio konceptom potrebe kako bi definirao pojmove, ali sam koncept potrebe nije ni definirao ni opisao. ${ }^{16}$ Na primjer, robu je definirao kao objekt izvan nas koji prema nekim svojim svojstvima zadovoljava određene ljudske potrebe. ${ }^{17}$ Međutim, to samo znači da roba ne može postojati a da ne postoji određena potreba, ali ne znači da ne postoji potreba koja se ne može zadovoljiti robom neke vrste. Kada bi to bio slučaj, iz toga bi uslijedilo da je potreba čisto ekonomski koncept. Ili ne bi postojala potreba za umjetnošću ili umjetnost ne bi zadovoljavala Marxov zahtjev da bude sama sebi svrha. No u djelu Economic and Philosophic Manuscripts of 1844 [Ekonomsko-filozofski rukopisi iz 1844.] otkrivamo da je Marx na sličan način odbacio i takav stav: „Društvo-kako se ono čini političkom ekonomistu-jest građansko društvo, u kojem je svaki individuum cjelina potreba i postoji za drugoga kao što i drugi postoji za njega samo ako jedan drugome postaje sredstvo." ${ }^{18}$ Što bi bila alternativa ovom stavu „političkog ekonomista”? Smatra li Marx da se čovjek može osloboditi svojih potreba (a time i svoje prirode, koju definira kao „ukupnost potreba i pobuda” ${ }^{19}$ ) ili nudi alternativni koncept potrebe koja se ne mora smatrati potpuno ekonomskom kategorijom? Čini se da nejasnoće u različitim prikazima koncepta potrebe proizlaze iz srednjovjekovne razlike između termina natura naturans i natura naturata. Kako se njegovo razlikovanje potreba razvijalo od djela Grundrisse der Kritik der politischen Ökonomie [Osnovne crte kritike političke ekonomije] do Kapitala, postalo je jasno da je granica između „prirodnih” ili „nužnih” potreba s jedne strane i "društveno uvjetovanih" potreba s druge strane izbrisana te da su čak i „prirodne” potrebe (primjer nature naturate) ustvari društveno uvjetovane (primjer nature naturans). Već u Grundrisseu Marx je zamijetio specifičan karakter gladi zadovoljene „nožem i vilicom”. ${ }^{20}$ Međutim, to ne znači da je nestalo „carstvo potrebe” koje uvjetuje postojanje takvih potreba. Marx je itekako svjestan da materijalna proizvodnja mora postojati čak i u besklasnom društvu: materijalne potrebe (za hranom, odjećom, utočištem) uvijek će postojati na način koji određuje materijalna proizvodnja. No što je s drugom vrstom potrebe? Ako je natura naturans, čovjekova aktivna priroda, ograničena na modificiranje njegovih prirodnih potreba u skladu sa socijalno-povijesnim okolnostima, Marxovo inzistiranje na definiranju čovjeka i umjetničkog djela kao cilja za sebe postalo bi neutemeljeno. Kao što napominje Heller, ponekad se čini da je upravo to slučaj: „U svojoj klasifikaciji ekonomskih potreba... status quo kapitalističkog društva često utječe na povijesno-filozofsko-antropološku klasifikaciju. Upravo je to, a ne nekakav zaostali feuerbachizam, razlog zašto Marx nije nadišao naturalistički koncept potrebe, premda je to često pokušavao." ${ }^{21}$ Doduše, očito je da se Marx ne slaže s naturalističkim stavovima. or art would fail to meet Marx's demand as being an end in itself. However, in his Economic and Philosophic Manuscripts of I844 we find Marx rejecting this position in very similar terms: "Society, as it appears to the political economist is civil society, in which every individual is a totality of needs and only exists for the other person, as the other exists for him, in so far as each becomes a means for the other." ${ }^{18}$ What would be the alternative to this position of the "political economist?" Does Marx think that man can be free of his needs (and, thus, his nature, which he defines as a "totality of needs and drives" ${ }^{19}$ ) or does he provide an alternative concept of need, which need not be conceived as an entirely economic category? It seems that the ambiguities in his various presentations of the concept of need stem from the medieval distinction between natura naturans and natura naturata. As his distinction of needs develops from Grundrisse to The Capital, it becomes clear that the line between "natural" or "necessary" needs on the one hand, and the "socially produced" needs on the other, is erased, and that even the "natural" needs (an instance of natura naturata) are in fact socially produced (an instance of natura naturans). Even as early as Grundrisse, Marx makes a remark about the specific character of hunger satisfied "with a knife and fork." ${ }^{20}$ However, that does not mean that the "realm of necessity" that conditions the existence of such needs vanishes. Marx is well aware that material production must take place even in the classless society: material needs (for food, clothes, shelter) will always exist in a way determined by the material production. But what of the other type of need? If natura naturans, man's active nature, is limited to modifying his natural needs in correspondence with socio-historical circumstances, his insistence on the treatment of man and artwork as an end in itself would be left ungrounded. As Heller notices, it sometimes seems that this is exactly the case: "In his classification of economic needs ... the status quo of capitalist society often influences the historical-philosophical-anthropological classification.

16

Heller, Theory of Need in Marx, 23.

17

Marx, Capital, vol. 1, 45

18

Marx, Economic and Philosophic Manuscripts of 1844 and the Communist Manifesto, 128.

19

Marx, Grundrisse, 245.

20

Isto, 92.

21

Heller, Theory of Need in Marx, 28.

22

Isto, 40.

23

Marx, German Ideology, 48.

24

Heller, Theory of Need in Marx, 52.

25

Isto, 34. 
Razmotrimo Aristotelovu poziciju: poiesis nam je potrebna kako bismo aktualizirali svoje dane prirodne potencijale. (Na primjer, naš se potencijal za znanje ostvaruje kroz mimetske aktivnosti. No to nas ostavlja u domeni nature naturate, a naša je aktivnost ograničena na proces razvijanja onoga što je prethodno dano u modusu potencijalnosti.) Ako Marx prihvaća tu pretpostavku, njegov koncept potrebe ostaje ograničen na područje ekonomije. Kao što je Heller zaključila, postoji korelacija između čovjekove potrebe i konkretnog objekta/aktivnosti koji bi tu potrebu trebali zadovoljiti. Potreba može biti uzrok tog objekta/aktivnosti, ali moguć je i obrnut slučaj: objekt/aktivnost može dovesti do potrebe. „Potreba i njezin objekt su ,trenuci', ,strane' jednog te istog kompleksa. No ako ne analiziramo statički model, već dinamiku ,društvenog tijela' (pod pretpostavkom da ,društveno tijelo' ima dinamiku), tada trenutak proizvodnje zauzima prvo mjesto: proizvodnja je ta koja stvara nove potrebe." 22 Marx prepoznaje to primarno stvaranje potreba kroz proizvodnju kao čovjekov prvi povijesni čin. ${ }^{23}$ Međutim, kapitalistički način proizvodnje u tom pogledu uvodi jedan novum: inverziju odnosa između sredstava i cilja. U sustavu „otuđenih potreba” ciljevi se pretvaraju u sredstva, a sredstva u ciljeve. Tako čovjek više nije glavni cilj drugoga čovjeka; sveden je na sredstvo stvaranja bogatstva ili zadovoljavanja drugih potreba. Isto vrijedi i za sve objekte. Heller daje jedan primjer izrazito kantovskog tona: trgovac dijamantima ne vidi njihovu estetsku ljepotu jer ga zanima jedino prometna vrijednost. ${ }^{24}$ Sve potrebe svedene su na jedan homogeni skup koji pripada političkoj ekonomiji. Što bi mogla biti alternativa? Ako pogledamo koncept potrebe koji Marx suprotstavlja kako „prirodnim” ili „nužnim” tako i „otuđenim” potrebama, pojmit ćemo ono što Heller naziva „slobodnim potrebama” ${ }^{25}$ - strukturu potreba koja je povezana s „carstvom slobode".

18

Marx, Economic and Philosophic Manuscripts of 1844 and the Communist Manifesto, I28.

19

Marx, Grundrisse, 245.

20

Ibid., 92.

21

Heller, Theory of Need in Marx, 28.

22

Ibid., 40.

23

Marx, German Ideology, 48 .

24

Heller, Theory of Need in Marx, 52.

25

Ibid., 34 .

26

Marx, Economic and Philosophical Manuscripts of I844 and the Communist Manifesto, 77 .

27

Marx, The Capital, Vol. 3, 8०7.

28

Heller, Theory of Need in Marx, 26.

29

Ibid., 38.
This, and not any lingering feuerbachism, is the reason why Marx does not go beyond the naturalistic concept of need, though he often tries to do so." ${ }^{21}$ However, it is clear that Marx does not side with naturalistic accounts. Let us consider Aristotle's position: we need poiesis in order to actualize our pre-given natural potentials (for example, our potential for knowledge actualizes through mimetic activities; but that still leaves us in the domain of natura naturata, and our activity is limited to the process of developing that which has previously been present in the mode of potentiality). If Marx accepts this premise, his concept of need remains limited to the domain of economy. As Heller notes, there is a correlation between man's need and the concrete object/activity that is meant to satisfy the need. The need can be the cause of the object/activity, but the reverse can also be the case: the object/activity can bring about the needs. "The need and its object are 'moments', 'sides' of one and the same complex. But if we analyse not one static model but the dynamic of a 'social body' (presupposing that a 'social body' has a dynamic), then the moment of production occupies first place: it is production that cre ates new needs." 22 Marx recognizes this primary creation of needs through production as man's first historical act. ${ }^{23}$ However, there is a novum introduced in this respect by capitalist modes of production: an inversion of the relation between means and ends. In a system of "alienated needs," ends turn to means and means turn to ends. Thus, man is no longer the main end of another man; he is reduced to the means of gaining wealth or satisfaction of other needs. The same is the case with all objects. Heller evokes an example that bears a distinctly Kantian tone: the dealer of diamonds is not able to perceive the aesthetic beauty of the diamonds, because he is only interested in their exchange value. ${ }^{24}$ All needs are reduced to one homogenous set pertaining to political economy. What could the alternative be like? If we look at the concept of need that Marx contrasts both to "natural" or "necessary" ones and the "alienated" ones, we will grasp what Heller calls "free needs" ${ }^{25}$ - a structure of need pertaining to the "realm of freedom." In the Economic and Philosophic Manuscripts of I844, Marx writes: "Man produces even when he is free from physical need and only truly produces in freedom therefrom." ${ }^{26}$ And in Volume 3 of The Capital he maintains: "The realm of freedom actually begins only where labour which is determined by necessity and mundane considerations ceases." ${ }^{27}$ Thus we can infer that the concept of need that is entirely an economic category is the result of the alienation of needs within capitalist modes of production, where the goal of production is no longer the satisfaction of needs (which are reduced to their place in the market), but valorisation of capital. ${ }^{28}$ However, the needs that are to be satisfied here are not primarily the natural or necessary needs of the workers, but their needs of development. There is one more caveat in place here: this is not the development of their pre-given natural potentials, but "the free development of all the capacities and senses of the human being, the free and many-sided activity of every individual." ${ }^{29}$ Thus, the goal is to develop what Heller calls "heterogeneous 
U svojem djelu Economic and Philosophic Manuscripts of 1844 Marx piše: „Čovjek proizvodi i kad je slobodan od fizičke potrebe te istinski proizvodi tek oslobođen od nje." 26 A u trećoj knjizi Kapitala tvrdi: „Carstvo slobode počinje ustvari tek tamo gdje prestaje rad koji je određen nevoljom i vanjskom svrsishodnošću." 27 Iz toga možemo zaključiti da je koncept potrebe kao potpuno ekonomske kategorije rezultat otuđenja potreba unutar kapitalističkih načina proizvodnje, u kojima cilj proizvodnje više nije zadovoljenje potreba (koje su svedene na svoje mjesto na tržištu), već valorizacija kapitala. ${ }^{28}$ Međutim, potrebe koje je ovdje potrebno zadovoljiti nisu prvenstveno prirodne ili nužne potrebe radnika, već njihove potrebe za razvijanjem. Sada dolazimo do još jednog upozorenja: ovdje nije riječ o razvoju njihovih danih prirodnih potencijala, već o „slobodnom razvoju svih kapaciteta i osjetila ljudskoga bića, slobodnim i višestranim aktivnostima svakog pojedinca”. ${ }^{29}$ Dakle, cilj je razviti ono što Heller naziva „heterogenim kvalitetama u vrstama potreba" koje uključuju estetske potrebe, potrebu za društvom, za zajedničkim postojanjem itd. ${ }^{30}$ Čovjek je tek tada u potpunosti ustanovljen kao natura naturans, slobodan da sam odredi vlastitu bit kao generičko, društveno biće. Dakako, Marx bi odbacio razliku između nature naturans i nature naturate kao „nedijalektičku”, ali korisna je za prikazivanje razlike između Marxova stava i naturalističke pozicije koju je običavao izbjegavati. Samo unutar tog okvira može zaista vrijediti Marxovo inzistiranje na konceptu čovjeka i umjetničkog djela kao cilja samog za sebe. U carstvu slobode, primarne su potrebe one koje su usmjerene prema „višim aktivnostima” i prema drugim ljudima, one koje se ne smatraju sredstvom, nego ciljem. Postoji još jedan, posljednji aspekt „slobodnih potreba” koji naglašava Heller: „Spiritualne i moralne potrebe neće biti utvrđene... svojim položajem u podjeli rada jer su to individualne potrebe (koje se ne mogu izraziti srednjom vrijednošću) i zbog toga što se njihovo zadovoljenje ne može kupiti." ${ }^{31} \mathrm{Na}$ taj se način potreba za umjetnošću itekako može koncipirati. To može biti individualna potreba za samorealizacijom bez komodifikacije svojih proizvoda. Drugim riječima, proizvodnja će i dalje biti donekle potrebna; umjetnička djela imat će svoje materijalne aspekte (knjige, slike, skulpture, građevine). No umjetničko djelo kao umjetnina, kao objekt nematerijalne potrebe, ne spada u domenu proizvodnje. Isto tako, umjetnička djelatnost, kao „slobodna djelatnost” (koja ne spada u carstvo nužnosti) ne mjeri se „društveno nužnim radnim vremenom", barem ne u drugoj fazi komunizma. Međutim, kao i u ostalim specijaliziranim djelatnostima, ostaje neodgovoreno pitanje umjetničke vještine te vremena i truda potrebnog za njezino postizanje. Potreba za umjetnošću prije svega je zamišljena kao potreba za stvaranjem umjetničkih djela, a ne kao njihova recepcija. Moglo bi se očekivati da će čin recepcije služiti i kao način samorealizacije te da će stoga uključivati specifičnu vrstu obrazovanja i iskustva, ali ta tema ostaje neistražena. qualities in types of needs" that would include aesthetic needs, the need for society, the need for communal existence etc. ${ }^{30}$ Man is only then fully established as natura naturans, as free to self-determine his own essence as a generic, social being. To be sure, Marx would dismiss the distinction between natura naturans and natura naturata as "non-dialectical," but it is of use in depicting the distinction between Marx's position and the naturalistic position he tends to avoid. It is only within this framework that Marx's insistence on the concept of man and artwork as an end in itself can properly hold. In the realm of freedom, primary needs are those directed toward "higher activities" and towards other people, seen not as means but as ends. There is one final aspect of "free needs" that Heller emphasizes: "Spiritual and moral needs will not be fixed... by their position in the division of labour because they are individual needs (they cannot be expressed by any average) and because their satisfaction is not purchasable." ${ }^{31}$ Thus the need for art can well be conceived. It can be an individual need for free self-realization without commodification of its products. That is to say, production will still be necessary to some extent; artworks will still have their material aspect (books, paintings, sculptures, buildings). But the artwork as artwork, as an object of a non-material need, does not belong to the sphere of production. Likewise, artistic activity, as "free activity" (not belonging to the realm of necessity) is not measured in terms of "socially necessary labour time," at least in the second phase of communism. However, as in every specialized activity, there remains an unsolved question about artistic mastery and the time and effort necessary to acquire it. The need for art is primarily envisioned as the need to create artworks, and not as reception. One would expect that the act of reception should also serve as a means for self-realization, and thus include a specific sort of education and experience, but this topic remains unthematized.

26

Marx, Economic and Philosophical Manuscripts of 1844 and the Communist Manifesto, 77. 27

Marx, Capital, vol. 3, 807. 28 Heller, Theory of Need in Marx, 26. 29 Isto, 38. 30 Marx, Economic and Philosophical Manuscripts of 1844 and the Communist Manifesto, 124. 31

Heller, Theory of Need in Marx, 34. 32 Lipshitz, The Philosophy of Art of Karl Marx, 99. 33 Isto, 102-103. 
ZAKLJUČAK :

PROSTITUIRANA I EMANCIPIRANA

UMJETNOST

Za razliku od proizvodnje i komodifikacije umjetnosti u kapitalističkim sustavima, Marx je inzistirao da je svaka analogija između materijalne i spiritualne proizvodnje samo površinska. U strogom smislu, umjetnička proizvodnja ne može postojati. Kao što kaže Mikhail Lipshitz: „On je ismijavao svaki pokušaj predstavljanja umjetnika, pisaca i ekonomista kao ,produktivnih radnika u Smithovu smislu riječi' jer navodno proizvode , ne samo proizvode sui generis nego proizvode materijalnog rada i stoga, izravno, bogatstvo'. Svi ti pokušaji pokazuju da ,buržoazija prepoznaje i oprašta čak i najviše oblike spiritualne proizvodnje samo zato što su oni [umjetnici, pisci itd.] predstavljeni i lažno obilježeni kao direktni proizvođači materijalnog bogatstva'." ${ }^{32}$ Međutim, čak i kad su prepoznati kao takvi, umjetnici su predmet prezira, ,zanijekanog nimbusa” i „prostituirani”. Pa ipak, Marx vidi i drugu stranu tog „estetskog nihilizma” kapitalističkog načina proizvodnje-on također služi kao moćan revolucionarni faktor: „Kontrast između stvarnog položaja umjetnosti u kapitalizmu i golemih mogućnosti koje umjetnosti otvara razvoj proizvodnih moći društva tek je jedan primjer općih društvenih kontradikcija ,buržujskog razdoblja povijesti'. Budućnost umjetnosti i književnosti usko je povezana s rješavanjem tih proturječja-a ta rješenja, naravno, neće pasti s neba." ${ }^{33}$ lako Marx hvali buržoaziju zbog stvaranja masivnoga materijalnog bogatstva, odlučno tvrdi da je buržoazijsko društvo potpuno nesposobno iskoristiti to bogatstvo u svrhu kulturnog razvoja, upravo zbog ograničenja koja nameće čovjekova eksploatacija čovjeka. Jedino revolucija može ukinuti kontradikciju između materijalne i duhovne proizvodnje kao što je umjetnost. No što će umjetnost tada postati? Hoće li, kao bitno individualna aktivnost, nestati u tom novom kolektivizmu? Marx je optimističan po pitanju budućnosti umjetnosti. $U$ djelu The German Ideology [Njemačka ideologija] odgovara na jednu takvu primjedbu koju je dao Stirner:

30

Marx, Economic and Philosophical Manuscripts of 1844 and the Communist Manifesto, I24.

31

Heller, Theory of Need in Marx, 34 .

32

Lipshitz, The Philosophy of Art of Karl Marx, 99.

33

Ibid., IO2-IO3.

34

Marx, The German Ideology, 417-418.

\section{CLOSURE : \\ ART PROSTITUTED AND \\ EMANCIPATED}

As opposed to the production and commodification of art in capitalist systems, Marx insists that all analogies between material and spiritual productions are only superficial. In the strict sense, there can be no art production. As Mikhail Lipshitz notes: "He ridiculed every attempt to represent artists, men of letters and economists as 'productive workers in Smith's sense' because they allegedly produce 'not simply products sui generis, but products of material labor and, therefore, directly, wealth'. All these attempts show that 'even the highest forms of spiritual production are recognized and forgiven by the bourgeoisie only because they [artists, men of letters, etc.] are represented and falsely labelled as direct producers of material wealth." ${ }^{32}$ However, even when recognized as such, artists are objects of contempt, "stripped of their halo" and "prostituted." Still, Marx sees a different side of this "aesthetic nihilism" of the capitalist mode of production-it also serves as a powerful revolutionizing factor: "The contrast between the actual position of art under capitalism and the enormous possibilities opened up for art by the development of the productive powers of society is merely one instance of the general social contradictions of "the bourgeois period of history." The future of art and literature is closely bound up with the solution of these contradictions - which solution cannot be expected, of course, to drop from heaven." 33 Although Marx praises the bourgeoisie for the creation of massive material wealth, he is determined that bourgeois society is quite incapable of utilizing that wealth for purposes of cultural development, precisely because the limitations imposed by exploitation of man by man. It is only through revolution that the contradiction between material production and spiritual production, such as art, can be abolished. But what becomes of art then? Will it vanish in this new collectivism, being an essentially individual effort? Marx's position on the future of art is optimistic. In The German Ideology he replies to one of such objections, posed by Stirner:

The exclusive concentration of artistic talent in particular individuals, and its suppression in the broad mass which is bound up with this, is a consequence of division of labour ... In any case, with a communist organisation of society, there disappears the subordination of the artist to local and national narrowness, which arises entirely from division of labour, and also the subordination of the individual to some definite art, making him exclusively a painter, sculptor, etc.; the very name amply expresses the narrowness of his professional development and his dependence on division of labour. In a communist society there are no painters but only people who engage in painting among other activities. ${ }^{34}$ 
Isključiva koncentracija umjetničkog talenta kod pojedinaca, a s tim u vezi i njegovo gušenje u širokim masama, posljedica je podjele rada... U svakom slučaju, u komunističkoj organizaciji društva nestaje podređenost umjetnika lokalnoj i nacionalnoj ograničenosti, koja proizlazi samo iz podjele rada, kao i podčinjavanje pojedinca nekoj određenoj umjetnosti tako da postaje isključivo slikar, kipar itd.; sam naziv dovoljno izražava ograničenost njegova profesionalnog razvoja i njegovu ovisnost o podjeli rada. U komunističkom društvu ne postoje slikari, već samo ljudi koji se, između ostalog, bave i slikarstvom. ${ }^{34}$

Postoji još jedna posljednja razlika koju bi komunističko društvo izbrisalo: razlika između nužnih i luksuznih potreba-potonje predstavlja „podoban” položaj umjetnosti unutar kapitalističkih načina proizvodnje. Umjetnost bi prestala biti razonoda bogatih, jer se danas imućnost shvaća kao bogatstvo potpuno ostvarenoga ljudskog bića u ukupnosti svojih životnih aktivnosti.
There is one final distinction that a communist society would erase: the distinction between necessary and luxury needs - the latter being the "proper" place of art within capitalist modes of production. Art would cease to be a pastime for the wealthy, as wealth is now conceived as the richness of the fully actualized human being in the totality of his life-activities. 


\section{POPIS LITERATURE / BIBLIOGRAPHY}

Arvon, Henry. Marxist Esthetic. Ithaca/London: Cornell University Press, 1973.

Graham, Gordon. Philosophy of the Arts, an Introduction to Aesthetics. London: Routledge, 2006.

Heller, Agnes. Theory of Need in Marx. London: Allison \& Busby, 1978.

Kant, Immanuel. Groundwork for the Metaphysics of Morals. New Haven/London: Yale University Press, 2002.

Koch, Hans. Marxismus und Ästhetik. Berlin: Dietz Verlag, 1961.

Lipshitz, Mikhail. The Philosophy of Art of Karl Marx. London: Pluto Press Limited, 1976

Lukács, Georg. „Einführung in die ästetischen Schriften von Marx und Engels", 205-231. U/In: Georg Lukács Werke (Band 10): Probleme der Ästhetik. Neuwied: Luchterhand, 1969.

Marx, Karl, Engels, Friedrich. Collected Works, Vol. 35: Capital, vol. 1. London: Lawrence \& Wishart, 1996.

Collected Works, Vol. 37: Capital, vol. 3. London: Lawrence \& Wishart, 1998

The Communist Manifesto. London: Pluto Press, 2008.

The German Ideology. Amherst NY: Prometheus Books, 1998.

Marx, Karl. „Debating the Freedom of the Press”, 60-61. U/In: Marx \& Enge/s on Literature and Art, ur./ed. Lee Baxandall, Stefan Morawski. St. Louis/Milwaukee: Telos Press, 1973.

Economic and Philosophical Manuscripts of 1844 and the Communist Manifesto. Amherst: Prometheus Books, 1988.

Grundrisse. Toronto: Random House, 1973

„Remarks on the Instructions to the Prussian Censors”, 59-60. U/In: Marx \& Engels on Literature and Art, ur./ed. Lee Baxandall, Stefan Morawski. St. Louis/Milwaukee: Telos Press, 1973.

„Theories of Surplus Value”, 64. U/In: Marx \& Engels on Literature and Art, ur./ed. Lee Baxandall, Stefan Morawski. St. Louis/ Milwaukee: Telos Press, 1973.

Morawski, Stefan. „The Aesthetic Views of Marx and Engels”. The Journa of Aesthetics and Art Criticism 28/3 (proljeće/Spring 1970.): 301-314.

Prawer, Siegbert Salomon. Karl Marx and World Literature. Oxford: Oxford University Press, 1978.

Rose, Margaret A. Marx's Lost Aesthetic: Karl Marx and the Visual Arts. Cambridge: Cambridge University Press, 1984

Werckmeister, Otto Karl. „Marx on Ideology and Art”. New Literary History 4/3 (proljeće/Spring 1973.): 501-519. 